\title{
Morpho-physiological response to vertically heterogeneous soil salinity of two glycophyte woody taxa, Salix matsudana $x$ S. alba and Eucalyptus camaldulensis Dehnh
}

\author{
Adriana S. Quiñones Martorello • Javier E. Gyenge • \\ María Elena Fernández
}

Received: 19 September 2016 / Accepted: 8 March 2017

(C) Springer International Publishing Switzerland 2017

\begin{abstract}
Aims Growth and physiology of Salix matsudana $x S$. $a l b a$ and $E$. camaldulensis were evaluated in vertical saline gradients to test whether growth is determined by the mean salinity of rhizosphere, the average salinity weighed by the root number in each portion of the soil, the lowest or the highest rhizosphere salinity.

Methods Saplings were grown in pots with an original irrigation system determining upper and lower soil layers with a combination of 4 treatments: control, moderate homogeneous salinity (Ho), and heterogeneous salinity, with high concentration of $\mathrm{NaCl}$ in the upper $(\mathrm{HeU})$ or in the lower soil layer (HeL).

Results E. camaldulensis saline treatments decreased $\Psi_{\text {pre-dawn }}$ and $\Psi_{\text {osmotic }}$. HeU and HeL did not decrease stem growth (RVG), but HeL reduced root biomass in lower soil layer. Ho treatment reduced RVG (50\%), increasing leaf senescence and altering some ions concentration (but not $\mathrm{Na}^{+}$). In Salix sp., Ho decreased $\Psi_{\text {pre- }}$ dawn and chlorophyll content, increasing leaf senescence
\end{abstract}

Responsible Editor: Frans J.M Maathuis.

A. S. Quiñones Martorello · J. E. Gyenge · M. E. Fernández Consejo Nacional de Investigaciones Científicas y Técnicas, CONICET, Buenos Aires, Argentina

A. S. Quiñones Martorello ( $₫)$

Universidad Nacional de Mar del Plata, EEA INTA Balcarce, Ruta 226, km 73,5, Balcarce, Buenos Aires, Argentina

e-mail: adriana.silvia.quinones@gmail.com

J. E. Gyenge · M. E. Fernández

AE INTA Tandil, Rodriguez 360, Tandil, Buenos Aires, Argentina and $\mathrm{Cl}^{-}$concentration resulting in low leaf biomass. $\mathrm{HeL}$ also decreased plant total biomass.

Conclusions Lower concentration of salt homogeneously distributed in soil profile would have more effect than high salt concentration but restricted to one soil layer. The negative impact of high salinity would be higher if salts are in deeper than in upper soil layers. Salt tolerance thresholds would then depend more on the salt spatial distribution in the soil than on its average concentration along the rhizosphere.

Keywords Soil salinity gradients $\cdot$ Eucalyptus camaldulensis · Salix matsudana x S. alba "NZ 26992" . Hydric conditions · Growth · Leaf ions concentration

$\begin{array}{ll}\begin{array}{l}\text { Abbreviations } \\ \text { 0\% DLB }\end{array} & \begin{array}{l}\text { Fully green leaves without } \\ \text { apparent damage biomass } \\ \text { Proportion between 0\%DLB } \\ \text { and TLB }\end{array} \\ \text { 1-50\% DLB } & \begin{array}{l}\text { Leaves biomass with } \\ \text { senescence symptoms in } \\ \text { less than the 50\% of their } \\ \text { surface }\end{array} \\ \text { 1-50\%DLB/TLB } & \begin{array}{l}\text { Proportion between 1 and } \\ 50 \% \text { DLB and TLB } \\ \text { Leaves biomass with }\end{array} \\ & \begin{array}{l}\text { senescence symptoms in } \\ \text { more than the 50\% of } \\ \text { their surface } \\ \text { Proportion between 50 DLB } \\ \text { and 100\%DLB and TLB }\end{array}\end{array}$


C

EC

HeL

gs

$\mathrm{HeU}$

Ho

L

LRB

LRB/TRB

RVG

SB

ShB

$\mathrm{ShB} / \mathrm{TB}$

$\mathrm{TB}$

TLB

TRB

U

URB

URB/TRB

$\Psi_{\text {pre-dawn }}$

$\Psi_{\text {osm }}$
Control, pot irrigated with tap water

Electrical conductivity of the soil

Salt gradient with higher EC in the lower layer

Stomatal conductance

Salt gradient with higher EC in the upper layer

Homogeneus salt distribution

Lower soil layer of the pot

Root biomass in the lower soil layer

Proportion between LRB and TRB

Relative volume growth

Stem biomass

Shoot biomass, SB + TLB

Proportion between ShB and TB

Total biomass, ShB + TRB

Total leaves biomass

Total root biomass

Upper soil layer of the pot

Root biomass in the upper soil layer

Proportion between URB

and TRB

Pre dawn shoot water

potential

Osmotic potential

\section{Introduction}

Soil salinity, resulting from natural processes or from crop irrigation with saline water, occurs in many arid to semi-arid regions of the world (Läuchli and Epstein 1990). This problem affects more than 80 million ha of arable land worldwide (Munns and Tester 2008; Ismael et al. 2014), with estimated annual global costs equivalent to several thousand million dollars each year (FAO 2011).

Horizontal and vertical variations in the salinity of the soil solution occur because of the interplay between soil leaching events, which are triggered by rainfall, irrigation and water infiltration; and the evapo-concentration of

solutes, due to evaporation from moist soil surfaces and water extraction by roots (Bennett et al. 2009). Along with the above mentioned, another common cause of increased soil salinity is the upward ion movement due to the development of shallow water tables as a result of over irrigation or the loss of deep-rooted perennial vegetation. In these landscapes water and ions move from the shallow groundwater to the soil surface, particularly at times of high evaporative demand (Ghassemi et al. 1995; Bleby et al. 1997; Northey et al. 2006), generating a vertical gradient characterized by more salts in relatively deep layers than in upper ones, opposed to the type of vertical gradient resulting from irrigation with saline water. Furthermore, salt becomes progressively concentrated in the root zone. Roots of most glycophyte plants, unlike halophytes, absorb water but very little salt, therefore reaching a different threshold of salt accumulation depending on the tolerance of the species to the stress produced by soil salinization (Nosetto et al. 2008). Salt heterogeneity in soil can be further exacerbated by the fact that dissolved salts can interact with the solid soil matrix (e.g. through adsorption) and also precipitate when their concentration exceed their solubility (e.g. common in soils with high gypsum content, Robbins et al. 1980).

Although soil salinity is heterogeneously distributed in horizontal as well as in vertical gradients, consequently affecting differentially the root zone, most greenhousebased studies of plant physiological responses to salinity have been investigated within uniform salinity conditions in the growing substrate (e.g. Flowers and Colmer 2008; Munns and Tester 2008). Improvements in methodological approaches, trying to mimic more realistic conditions have been applied in several studies in which plants are subjected to heterogeneous salinity distribution through "Split-Root" experiments. In these experiments, the root system is divided into two or more portions which are exposed to different salinity conditions generating salt gradients in horizontal distribution (e.g. studies in nonhalophytic crop species: Zekri and Parson 1990; Shani et al. 1993; Flores et al. 2002; Dong et al. 2011; Koushafara et al. 2011; Kong et al. 2012; studies in halophytes: Messedi et al. 2004; Hamed et al. 2008; Bazihizina et al. 2009; Bazihizina et al. 2012b). However, few studies have been carried out emulating the vertical gradients of soil salinity (exceptions are studies in alfalfa by Shalhevet and Bernstein 1968, and in sweet corn by Bingham and Garber 1970) but none research has proven these vertical gradients in a woody 
species. Studies concerning vertically heterogeneous salinity are very limited presumably due to difficulties in applying and maintaining treatments (reviewed in Bazihizina et al. 2012a). However, given that vertically heterogeneous salinity is the more common phenomenon in saline landscapes there is a need to develop new protocols and methods to fill this gap in knowledge.

Based on this information, in this study we have developed a new and cheap experimental system which is able to create different vertical salinity gradients in pots. The species chosen to study the effects of different vertical salinity patterns on physiological and morphological responses were juvenile individuals of Salix matsudana x S. alba (clone "NZ 26992") and Eucalyptus camaldulensis Dehnh, two woody species known for economic interest for cultivated forests worldwide. From a biological point of view, they were chosen as model species due to their differential root system architecture and abiotic stress resistance. Regarding this, E. camaldulensis is a phreatophyte species, whose root system consists of a tap root and original lateral roots, developing deep roots to explore the soil to great depths. Is able to resist alkaline conditions ( $\mathrm{pH} 7-9.5$ ) and quite high soil salinity (from $8 \mathrm{dS} /$ m) (Pardos 2007; Merchan et al. 2007) to $42 \mathrm{dS} / \mathrm{m}$ (Feikema et al. 2012) and is low or moderately tolerant to waterlogging (Sena Gomes and Kozlowski 1980; Van der Moezel et al. 1989; Marcar et al. 2002, Argus et al. 2015). In contrast, Salix species develop adventitious stem roots, are able to support water excess and have moderate to low drought and salinity tolerance. In spite of Hangs et al. (2011) had shown that several Salix species can withstand salinity levels from 5 to $8 \mathrm{dS} / \mathrm{m}$, previous studies have shown that Salix matsudana $x$ alba "NZ 26992" could only develop roots up to a average salinity of $5 \mathrm{dS} / \mathrm{m}$ (Quiñones Martorello et al. 2012, 2014). While there is a wide literature on the effects of salinity when it is applied uniformly in different growth conditions or combined with waterlogging for both Eycalyptus camaldulensis (Woodward and Bennett 2005; Cha-um and Kirdmanee 2010; Isla et al. 2014; Sixto et al. 2016) and Salix sp. (Hangs et al. 2011; Qiao et al. 2013; Quinn et al. 2015), there is no information on the response of these species to heterogeneous conditions of soil salinity.

Shoot growth is tightly linked with root development patterns and, in heterogeneous saline soils, may depend upon increased root growth in the least saline areas (Bazihizina et al. 2012a, b). For glycophyte species, it has been found that most roots grow in the least or non saline zones (e.g. Citrus aurantium (Zekri and Parsons 1990) and Solanum lycopersicum (Flores et al. 2002)). Previous research on halophyte woody species like Atriplex nummularia demonstrated that growing under heterogeneous salinity conditions applying the splitroot system leads to responses related to the average salinity weighed by the number of roots in each portion of the gradient (Bazihizina et al. 2009, Bazihizina et al. 2012a, b). However, based on contrasting results obtained in woody and shrubs species undergoing split-roots experiments (Shani et al. 1993 in grapevine, Dong et al. 2011 and Kong et al. 2012 in cotton) and the lack of antecedents for vertical gradients in woody species, we could not state a unique hypothesis. Instead, we proposed four alternative hypotheses to be tested: growth and other physiological responses of Salix matsudana x S. alba "NZ 26992" and Eucalyptus camaldulensis were determined by: H1) the mean salinity of rhizosphere, H2) the average salinity weighed by the root number in each portion of the soil; H3) the lowest, or H4) the highest rhizosphere salinity.

\section{Materials and methods}

Plant material and growth conditions

We used $50 \mathrm{~cm}$ long cuttings of a commercial clone of Salix matsudana x Salix alba "NZ 26992" (Salix sp.), with an average diameter of $13 \mathrm{~mm}$, provided by the Genetic Improvement Programme of INTA (National Institute for Agricultural Technology, Argentina), and Eucalyptus camaldulensis (Eucalyptus sp.) saplings, with a mean height of $62 \mathrm{~cm}$ and a mean basal diameter of $6 \mathrm{~mm}$, produced by a commercial nursery.

The cuttings and saplings were placed in 151 pots filled with a $1: 1$ soil and sand mixture, with $\mathrm{pH}=7.94$ and electrical conductivity $(\mathrm{EC})=0.253 \mathrm{dS} / \mathrm{m}$ (dilution 1:2.5 -soil mix: distilled water). The pots were previously adapted to drip irrigation as described in the next section. The plants were kept under greenhouse conditions for a period of 40 days (August-September 2013) in order for the roots to explore the whole pot. Average air temperature during this period was $20 \pm 3^{\circ} \mathrm{C}$ and the average air relative humidity was $60 \%$. The plants were 
watered every two days with tap water $(\mathrm{EC}=0.96 \mathrm{dS} /$ $\mathrm{m})$, at a rate of 11 per pot (0.5 1 in each soil layer).

\section{Experimental system}

The 151 pots were adapted to two handmade drip irrigation devices made of a plastic 2.51 bottle connected to a $1 \mathrm{~m}$ long and $25.4 \mathrm{~mm}$ in diameter polyethylene hose. On the other end was attached a ring made of hose of the same diameter pierced at $50 \mathrm{~mm}$ intervals to allow dripping (Fig. 1). Each junction was sealed and checked to avoid water leakage. The pots were drilled in the bottom to allow drainage of excess water or salt solution after irrigation.

The pots were assembled, from the lower to the upper part, as follows: $20 \mathrm{~cm}$ of soil mix, then the first irrigation device to provide water to the lower soil layer (L); another $20 \mathrm{~cm}$ of soil mix and above it the second device to provide water to the upper soil layer (U). A final layer of $5 \mathrm{~cm}$ of soil mix was placed to support the upper device. The pots were therefore divided into two layers, $\mathrm{L}$ and $\mathrm{U}$, each one $20 \mathrm{~cm}$ deep and with a weight of $10 \mathrm{~kg}$ (Fig. 1). A water retention curve was performed with the soil mix in order to set the irrigation volume in each layer (50\% of available water) just to minimize water drainage from the upper to the lower layer. Volumetric soil water content was also estimated periodically using a TDR device (Soil moisture Equipment
Corp., Trase System I 6050X1-1996, Santa Bárbara, California, USA) in order to adjust the amount of water added to each layer.

The experiment was carried out in a greenhouse. During the whole period of measurements, average day/night temperature was around $25 / 10{ }^{\circ} \mathrm{C} \pm 2$ and air relative humidity was $64 \pm 9.5 \%$. Mean photosynthetically active radiation at noon was $757 \pm 200 \mu \mathrm{mol}$ $\mathrm{m}^{-2} \mathrm{~s}^{-1}$. Plants were distributed in four treatments: Control $\mathrm{C}=$ irrigated with tap water to both layers $(\mathrm{EC}=0.96 \mathrm{dS} / \mathrm{m})$; Heterogeneous salinity by irrigation with $\mathrm{NaCl}$ solution in high concentration $(5 \mathrm{dS} / \mathrm{m}$ for Salix sp. and $8 \mathrm{dS} / \mathrm{m}$ for Eucalyptus sp.) in the upper layer and tap water in the lower layer = HeU; Heterogeneous salinity by irrigation with $\mathrm{NaCl}$ solution in high concentration $(5 \mathrm{dS} / \mathrm{m}$ for Salix sp. and $8 \mathrm{dS} / \mathrm{m}$ for Eucalyptus sp.) in the lower layer and tap water in the upper layer = HeL; and Homogeneous salinity by irrigation with $\mathrm{NaCl}$ solution in moderate concentration in both layers $(2,5 \mathrm{dS} / \mathrm{m}$ for Salix $s p$. and $4 \mathrm{dS} / \mathrm{m}$ for Eucalyptus $s p$. $)=$ Ho. Each treatment had seven replicates for each tree species placed in randomized complete blocks. The treatments were carried out for 40 days during October-November 2013. Electrical conductivity of soil was measured weekly, in four replicates of each treatment with a Field Scout Soil and Water EC Meter (Spectrum Technologies, Inc.; 12360S, Industrial Dr. East Plainfield, IL 60585 USA). The EC

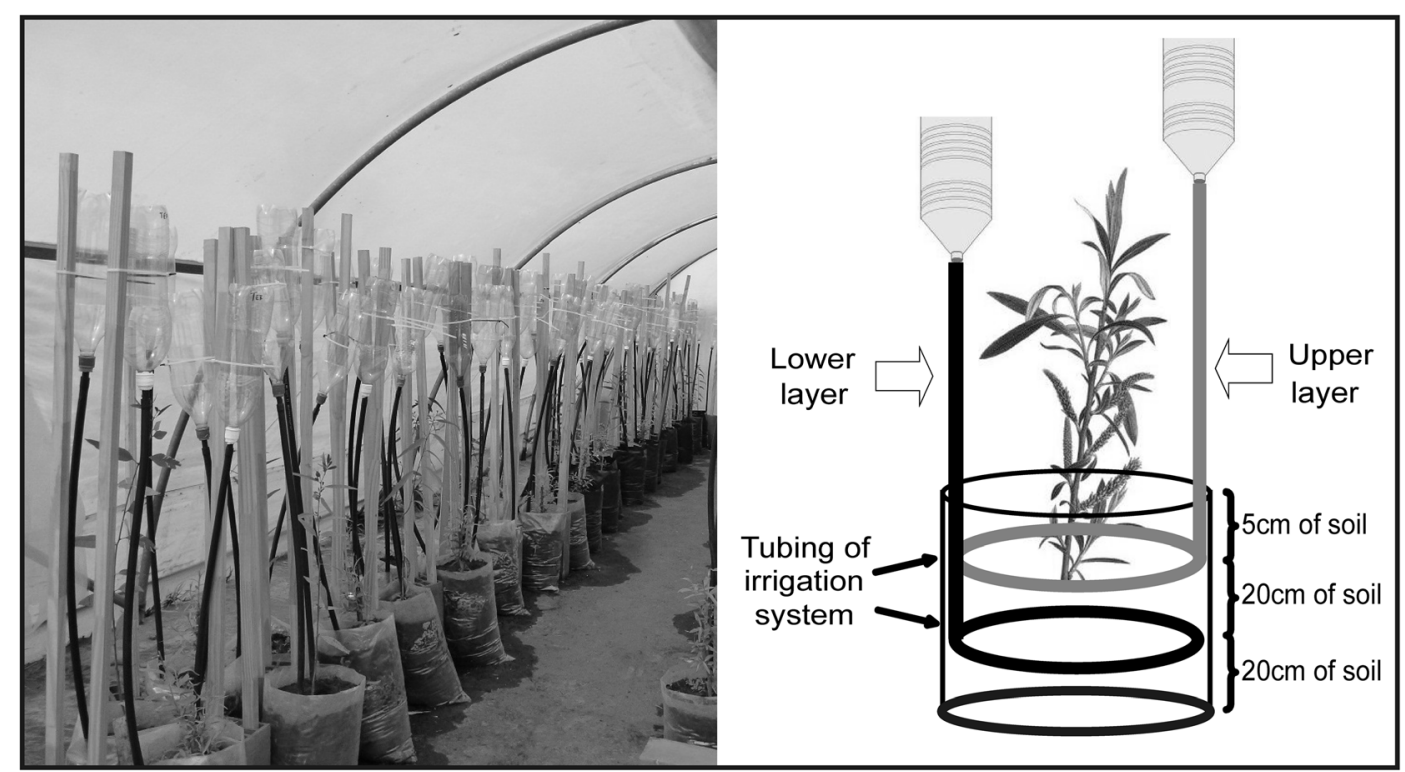

Fig. 1 Left Panel: View of the experimental device at the beginning of treatments imposition. Right Panel: Schematic drawing of the experimental device 
measurement was performed one hour after watering the pots with water or saline solution to ensure excess water drainage. At the end of the experiment, a soil sample was collected in each layer of the pot in four pots of each treatment and species. The soil samples were ground and passed through a $2 \mathrm{~mm}$ sieve. The EC was measured in a dilution of 1: 2.5 (10 g of soil $+25 \mathrm{ml}$ bi-distilled water). The sample was measured with a Table EC probe (OAKTON PC700 with Cole-Palmer pH probe 05992-62 and EC-temperature 35,608-74, USA).

Biomass production and allocation

At the end of the experiment, all plants were harvested, separating their biomass in compartments: leaves (LB), which were additionally separated into three categories depending on senescence-damage degree (see below), stem (SB), and root biomass (RB). Root biomass was also determined for each soil layer (see below). Total biomass $(\mathrm{TB}=\mathrm{LB}+\mathrm{SB}+\mathrm{RB})$ and shoot biomass $(\mathrm{ShB}=\mathrm{LB}+\mathrm{SB})$ were also estimated. Leaves were divided into three categories: fully green leaves without apparent damage (0\% leaf damage), and leaves with senescence symptoms (yellowing, necrosis or dehydration) in less than $50 \%$ of their surface $(1-50 \%$ leaf damaged) and those with a $50 \%$ or more area with senescence symptoms (50-100\% leaf damaged). To separate roots in each soil layer, pots were cut in half with a saw just above the watering device, and roots within each soil layer were washed to remove soil particles. Biomass samples of the different compartments were oven-dried at $60{ }^{\circ} \mathrm{C}$ to constant weight, and dry weight was determined with an analytical balance.

The following allometric variables and ratios were also estimated: $0 \%$ damaged leaf biomass/total leaf biomass (0\% DLB/TLB), 1-50\% damaged leaf/total leaf biomass (1-50\% DLB/TLB), 50-100\% damaged leaf/ total leaf biomass (50-100\% DLB/TLB), Shoot biomass/total biomass (ShB/TB), root biomass/total biomass, upper layer root biomass/total root biomass (URB/TRB) and lower layer root biomass/ total root biomass (LRB/TRB).

\section{Growth parameters}

For both species the stem relative volume growth (RVG) was calculated as the difference between the initial and final volume of the stem divided the initial volume. In
Eucalyptus sp., the stem volume was calculated through the diameter at the stem base and the height of all plants $(n=7)$ at the beginning and at the end of the experiment. In Salix sp., it was calculated by the diameter and height of the two main shoots generated in the first 40 days of growth. These measures allowed calculate the stem volume assuming its form as a cylinder. In Salix $s p$. cuttings, the relative diameter growth was also calculated to detect any possible change as a consequence of saline stress.

The length of the leaves at the end of the experiment was measured in healthy leaves with a digital caliper, taking into account the four longest leaves of four individuals of each treatment and species $(n=4)$.

Ecophysiological variables

Pre-dawn shoot water potential ( $\left.\Psi_{\text {pre-dawn }}, \mathrm{MPa}\right)$ was measured weekly on $10 \mathrm{~cm}$ long- shoot segments of four plants chosen at random from each treatment and species using a Scholander pressure chamber (BioControl, Inc., model $6 \mathrm{MPa}$, Argentina).

Stomatal conductance ( $\mathrm{gs}, \mathrm{mmol} \mathrm{m} \mathrm{m}^{-2} \mathrm{~s}^{-1}$ ) was measured weekly in four randomly chosen plants per treatment and species with a leaf porometer (Decagon Devices Inc., Model SC-1, Pullman, WA, USA). This variable was measured around 10 a.m., in young completely expanded leaves (one per plant), in order to record maximum daily gs in each treatment.

Leaf chlorophyll content was estimated weekly using SPAD (Model 502P, Spectrum Technologies Inc., East Plainfield, Illinois USA). The ratio of variable to maximum fluorescence $(\mathrm{Fv} / \mathrm{fm})$ was calculated as maximum quantum yield of PSII photochemistry using a fluorometer (HANSATECH, FMS2, Pulse modulated chlorophyll fluorescence monitoring system, UK) in four expanded leaves of four plants in each treatment and species which were pre-adapted to dark conditions for $30 \mathrm{~min}$. The state of photosystem II was assessed through $\mathrm{Fv} / \mathrm{fm}$ ratio. For the SPAD measurements the leaves were marked at the beginning and therefore monitored during the experiment or until its abscission.

Leaf osmotic potential $\left(\Psi_{\text {osmotic }}\right)$ was measured at the end of the experiment (40 days treatments) on four expanded leaves of four plants per treatment harvested and stored at $-80{ }^{\circ} \mathrm{C}$ in liquid nitrogen. Osmotic potential was determined with the dew-point method in ground samples within a C-52 Sample Chamber connected to a Wescor 
microvoltimeter (Wescor, HR33T Dew Point Microvoltimeter, Logan, Utah, USA). The concentration of anions $\left(\mathrm{Cl}^{-}, \mathrm{F}^{-}, \mathrm{NO}_{2}{ }^{-}, \mathrm{PO}_{4}{ }^{-}, \mathrm{SO}_{4}{ }^{=}\right)$and cations $\left(\mathrm{Na}^{+}, \mathrm{K}^{+}, \mathrm{Mg}^{+2}, \mathrm{Ca}^{+2}\right)$ in leaf tissue was determined in four plants of each treatment and species. A sample of 15 expanded leaves of each plant was oven-dried at $60{ }^{\circ} \mathrm{C}$, and then was ground to a powder and passed through a $0.3 \mathrm{~mm}$ sieve. $14 \mathrm{mg}$ of leaf powder was weighed and resuspended in $4 \mathrm{ml}$ of bi-distilled water. The extracts were shaken for $1 \mathrm{~h}$ and centrifuged at $6000 \mathrm{rpm}$. The supernatant was filtered with a membrane (MEM.MCE of $22 \mu \mathrm{m}$ and $13 \mathrm{~mm}$, Biopore SRL). One aliquot of $50 \mu \mathrm{l}$ was taken and analyzed by ion Shimadzu A20 HPLC, with CDD detector and autosampler injector. In the anions measurement, Mobile phase Sodium carbonate $3.6 \mathrm{mM}$ Column Shim-pack IC-SA3 was used (Shimadzu Co.), with pre-column and suppressing system; isocratic flow $0.8 \mathrm{ml} / \mathrm{min}$ for $25 \mathrm{~min}$ at $40{ }^{\circ} \mathrm{C}$. In cations determination, Mobile phase Ac. oxalic $3 \mathrm{mM}$, Shim-pack IC-IC-C3 C3G column with pre-column IC-C3G (Shimadzu Co.) was used, with isocratic flow $1.2 \mathrm{ml} / \mathrm{min}$ for $20 \mathrm{~min}$ at $40{ }^{\circ} \mathrm{C}$. Ions concentration determination was carried out in laboratories of the Institute of Plant Physiology and Genetic Resources (IFRGV) of INTA (Córdoba, Argentina).

\section{Statistical analysis}

Statistical analyses were carried out using $\mathrm{R}$ version 2.15.0 (Copyright 2012 the R Foundation for Statistical Computing ISBN 3-900,051-07-0). Two way analysis of variance (ANOVA) was first used to identify overall significant interactions between treatments and species $(\alpha=0.05)$. Post hoc comparisons (LSD Fisher and Tuckey test, $\alpha=0.05$ ) were then applied when interactions were significant in order to detect differences between treatments within each species. When interactions were not significant, data of each species were then analyzed separately with one way ANOVA. For variables measured in different dates (predawn potential, gs, SPAD determinations, Fv/fm and EC of the soil layers, both in absolute and relative values to the initial value for each plant), repeated measures ANOVA were used. In both cases, post-hoc comparisons were made with LSD Fisher test, with $\alpha=0.05$.

\section{Results}

Electrical conductivity measures indicate that the irrigation with $\mathrm{NaCl}$ solution in high concentration in the upper $(\mathrm{HeU})$ or in the lower $(\mathrm{HeL})$ soil layer generated a gradient of salt concentration in each pot, allowing to speak of layers with high or low salt concentration rather than saline or non saline soil layers. The experimental system developed in this study allowed to maintain these soil gradients or quite homogeneous soil salinity as expected (Fig. 2) at least during 20 days, however the measured electrical conductivity in the soil was much lower than that in the irrigation solutions (Table 1). In this regard, the EC (1: 2.5 dilution soil: distilled water) measured in soil samples of each layer at the end of the experiment indicated that the salt concentrations close to the desired ones were reached in the upper soil layer in $\mathrm{HeU}$ and Ho treatments, while in the lower layer of the HeL and Ho treatments, the EC (1:2,5) was lower than the expected value (Table 1), suggesting a high water (and salt) uptake in this soil layer by both Eucalyptus sp. and Salix sp.

Morpho-physiological response of eucalyptus sp. to salinity gradients

Nodifferences in total plant biomass $($ mean $=56.6 \pm 16.4 \mathrm{~g}$ per plant) were found between treatments. Similar values between treatments were also observed in shoot biomass (mean $=34.35 \pm 10.7 \mathrm{~g}$ per plant), and in stem biomass (mean $=16.01 \pm 5.5 \mathrm{~g}$ per plant). However, significant differences were observed between treatments comparing different leaf groups determined by visual signs of damage. The $0 \%$ leaf damaged and $1-$ $50 \%$ leaf damaged were similar between treatments, while 50-100\% leaf damaged was significantly higher in Ho respect to Control, HeU and HeL (Fig. 3 panel A). Therefore, $0 \%$ damaged leaf biomass /total leaf biomass showed the following differences $(p<0.05)$ : $\mathrm{C} \geq \mathrm{HeU}=\mathrm{HeL} \geq \mathrm{Ho}$, while $50-100 \%$ damaged leaf biomass/total leaf biomass showed an almost inverse pattern (Ho $\geq \mathrm{HeU}=\mathrm{HeL}=\mathrm{C}$ ). This indicates that in Eucalyptus sp. a moderate and homogenously distributed salinity generates a greater loss of leaf biomass than a high salinity concentration restricted to a single layer in the soil profile.

The Total Root Biomass (TRB) was $40 \%$ lower in $\mathrm{HeL}$ than in $\mathrm{C}(\mathrm{C}=\mathrm{HeU} \geq \mathrm{Ho} \geq \mathrm{HeL}$, Fig. 4). The highest difference in absolute root biomass was 


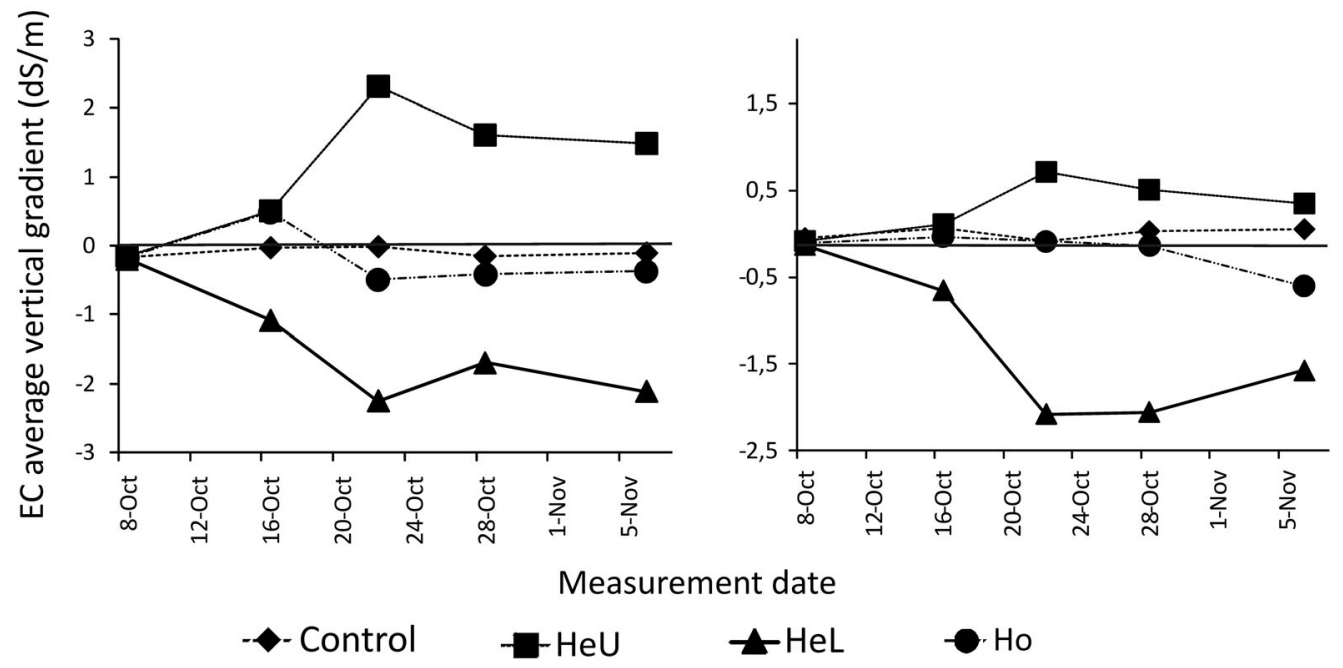

Fig. 2 Pattern of electrical conductivity (EC, dS/m) during the period of the experiment. Each point shows the difference: EC upper soil layer - EC lower soil layers of the pots. Left panel: Eucalyptus camaldulensis; Right panel: Salix matsudana $x$ S. alba

observed in the lower soil layer. In comparison with the control, the root biomass in the lower soil layer (LRB) decreased by $70 \%$ in HeL treatment and by $50 \%$ in the Ho treatment $(\mathrm{C} \geq \mathrm{HeU} \geq \mathrm{Ho} \geq \mathrm{HeL}, P$ 0.001) (Fig.4, panel A). As the root biomass in the upper layer (URB) did not present significant differences between treatments, the relationship URB/TRB was shown in the

Table 1 Electrical conductivity (EC, dS/m) in each layer of the pot in Eucalyptus camaldulensis (Eucalyptus sp.) and Salix matsudana x S. alba "NZ 26992" (Salix sp.) exposed to vertical
"NZ 26992". Treatments were $C=$ Control, $\mathrm{HeU}=$ salt gradient with higher EC in the upper layer, $\mathrm{HeL}=$ salt gradient with higher $\mathrm{EC}$ in the lower layer; $\mathrm{Ho}=$ homogeneous salinity

following order: $\mathrm{HeL}=\mathrm{Ho}>\mathrm{C}=\mathrm{HeU}$, while the lower layer root biomass/total root biomass ratio (LRB/TRB) presented the following: $\mathrm{C}=\mathrm{HeU}>\mathrm{HeL}=\mathrm{Ho}$. Therefore, from the total of roots produced in the treatment with high soil salinity in the lower soil layer, $78 \%$ were concentrated in the upper layer and only $22 \%$ were developed in the lower layer. It should be noted that in

gradients of salinity. EC (dS / m) was measured with a probe once a week during the experiment in four pots of each treatment and species

\begin{tabular}{clllllll}
\hline Taxa & Treatments & $\begin{array}{l}\text { EC Upper } \\
\text { layer } \\
\text { Probe }\end{array}$ & $\begin{array}{l}\text { EC } \\
\text { Upper layer } \\
\text { Dilution }(1: 2,5)\end{array}$ & $\begin{array}{l}\text { EC lower layer } \\
\text { Probe }\end{array}$ & $\begin{array}{l}\text { EC lower layer } \\
\text { Dilution }(1: 2,5)\end{array}$ & $\begin{array}{l}\text { EC } \\
\text { Average } \\
\text { of the pot. Probe }\end{array}$ & $\begin{array}{l}\text { EC } \\
\text { Average of the } \\
\text { pot. Dilution (1:2,5) }\end{array}$ \\
\hline Eucalyptus sp. & $\mathrm{C}$ & $0.36 \pm 0.07 \mathrm{a}$ & $0.75 \pm 0.1 \mathrm{a}$ & $0.46 \pm 0.1 \mathrm{a}$ & $0.65 \pm 0,1 \mathrm{a}$ & 0.41 & 0.7 \\
& $\mathrm{HeU}$ & $3.92 \pm 0.57 \mathrm{c}$ & $6.4 \pm 1.4 \mathrm{c}$ & $1.58 \pm 0.7 \mathrm{~b}$ & $2.7 \pm 0.5 \mathrm{~b}$ & 2.75 & 4.5 \\
& $\mathrm{HeL}$ & $1.07 \pm 0.75 \mathrm{ab}$ & $1.7 \pm 0.9 \mathrm{ab}$ & $3.07 \pm 0.6 \mathrm{c}$ & $2.6 \pm 0.1 \mathrm{~b}$ & 2.07 & 2.1 \\
& $\mathrm{Ho}$ & $1.99 \pm 0.67 \mathrm{bc}$ & $3.7 \pm 0.6 \mathrm{bc}$ & $2.40 \pm 0.7 \mathrm{bc}$ & $2.1 \pm 0.2 \mathrm{~b}$ & 2.20 & 2.9 \\
Salix sp. & $\mathrm{C}$ & $0.24 \pm 0.08 \mathrm{a}$ & $0.8 \pm 0.2 \mathrm{a}$ & $0.22 \pm 0.1 \mathrm{a}$ & $0.6 \pm 0.2 \mathrm{a}$ & 0.23 & 0.7 \\
& $\mathrm{HeU}$ & $1.76 \pm 0.3 \mathrm{c}$ & $4.2 \pm 0.9 \mathrm{c}$ & $1.24 \pm 0.6 \mathrm{~b}$ & $2.1 \pm 0.3 \mathrm{~b}$ & 1.50 & 3.1 \\
& $\mathrm{HeL}$ & $0.90 \pm 0.7 \mathrm{~b}$ & $1.4 \pm 0.3 \mathrm{ab}$ & $2.70 \pm 0.4 \mathrm{c}$ & $1.9 \pm 0.1 \mathrm{~b}$ & 1.80 & 1.6 \\
& $\mathrm{Ho}$ & $1.40 \pm 0.3 \mathrm{bc}$ & $2,2 \pm 0,5 \mathrm{~b}$ & $1.70 \pm 0.6 \mathrm{bc}$ & $1,85 \pm 0,1 \mathrm{~b}$ & 1.55 & 2
\end{tabular}

At the end of the experiment, soil samples of both layers were collected in four pots of each treatment and species, where EC was evaluated by soil dilution (1: 2.5: soil: demineralized water). The treatments were: Control (C), salinity heterogeneous ( $\mathrm{NaCl})$ with higher $\mathrm{EC}$ in the upper layer $(\mathrm{HeU})$, heterogeneous salinity with higher $\mathrm{EC}$ in the lower layer $(\mathrm{HeL})$ and homogeneous moderate salinity in the whole profile (Ho). The values correspond to the mean $\pm \mathrm{SD}, n=4$. "Probe" results correspond to the average of values during the whole study period, whereas the "Dilution" results report EC at the end of the experiment. The last two columns show the average values at the pot level, which should be similar in the three salinity treatments. Different letters between lines indicate significant differences between treatments (LSD Fi test, $P \leq 0.05$ ) 
Fig. 3 Damaged leaves biomass (\%) with three levels of damage $(0 \%, 1-50 \%$ and $50-100 \%)$ are shown, Panel A: Eucalyptus camaldulensis; Panel B: Salix matsudana x S. alba "NZ 26992". $\mathrm{C}=\mathrm{Control}, \mathrm{HeU}=$ salt gradient with higher $\mathrm{EC}$ in the upper layer, $H e L=$ salt gradient with higher $\mathrm{EC}$ in the lower layer;

$H o=$ homogeneous salinity. Values are means $(n=7) \pm$ s.e. Each bar represents different treatment, the letters indicate significant differences between treatments (post hoc Tuckey test; $P \leq 0.05)$

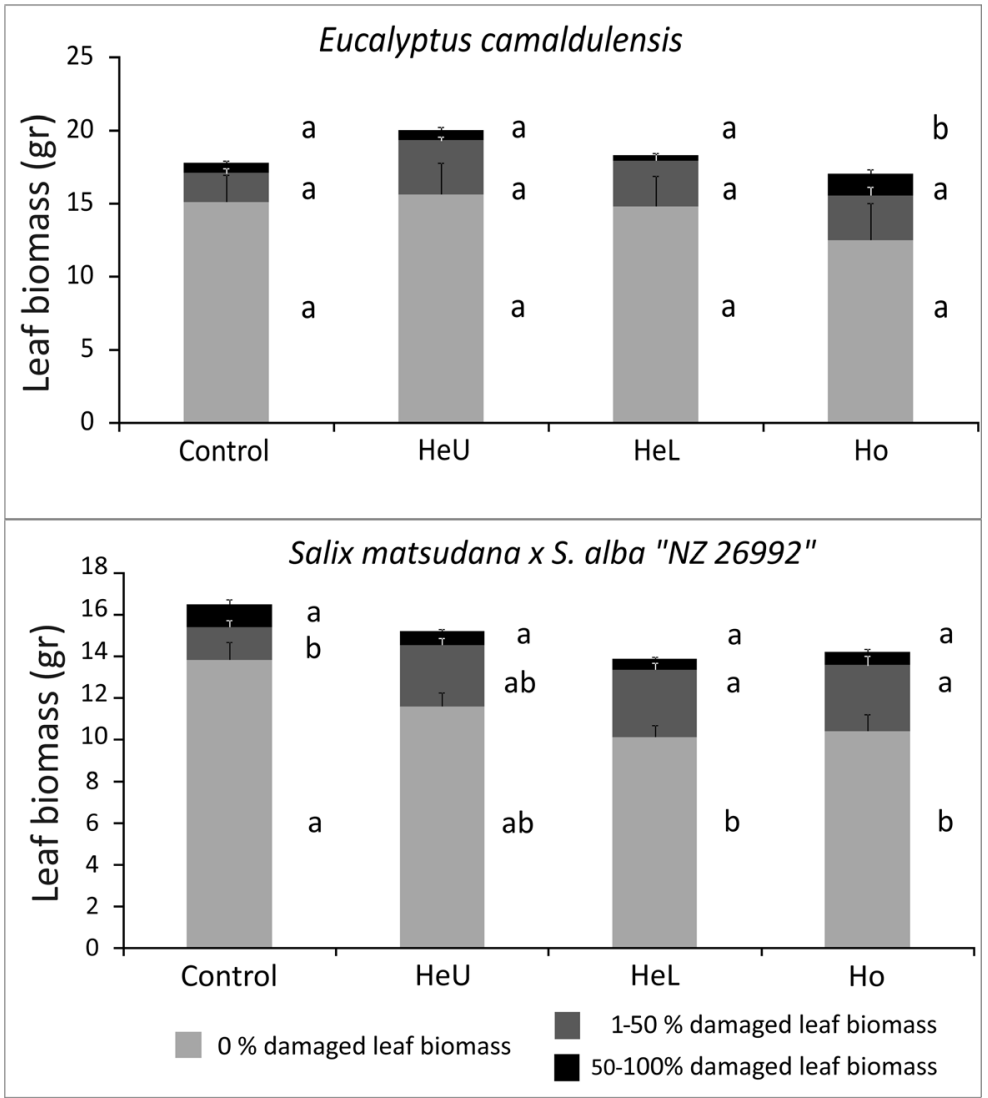

the control treatment root distribution, as measured as $\mathrm{URB} / \mathrm{TRB}$ and LRB/TRB, showed similar values $(0.55$ and 0.45 , respectively) proving that the experimental system in use allowed a quite homogenous root distribution within both soil layers.

No differences in stem relative volume growth (RVG) were observed between both treatments with heterogeneously distributed salt and $\mathrm{C}$, but in treatment with homogeneous salinity a decline of $48 \%$ in the RVG was observed compared with the control $(\mathrm{C} \geq \mathrm{HeU}=\mathrm{HeL} \geq \mathrm{Ho}$; Fig. 5). There were no significant differences in leaf length between heterogeneous or homogeneous salinity treatments and the control (C: $14.43 \mathrm{~cm} \pm 4.15$; HeU: $12.03 \mathrm{~cm} \pm 2.01$; HeL: $12.9 \mathrm{~cm} \pm 0.8$; Ho: $13.8 \mathrm{~cm} \pm 3.11$ ).

Regarding physiological variables, mean absolute value of $\Psi$ pre-dawn was lower in all salinity treatments than in control (mean value for the whole studied period: $\mathrm{HeU}=-0.62 \pm 0.15 \mathrm{MPa}, \mathrm{HeL}=-0.64 \pm 0.15 \mathrm{MPa}$, $\mathrm{Ho}=-0.66 \pm 0.12 \mathrm{MPa}, \mathrm{C}=-0.44 \pm 0.07 \mathrm{MPa}$; Fig. 6 panel A for values in each date). Relative chlorophyll content, as estimated by SPAD measurements, did not differ among treatments (Fig. 6 panel C), nor was damage in the Photosystem II estimated through chlorophyll fluorescence. In this regard, the mean absolute values of $\mathrm{Fv} / \mathrm{fm}$ were $0.83 \pm 0.02$ in $\mathrm{C}, 0.84 \pm 0.03$ in $\mathrm{HeU}, 0.83 \pm 0.03$ in $\mathrm{HeL}$, and $0.82 \pm 0.04$ in $\mathrm{Ho}$, indicating a good state of PSII in all treatments. In addition, no significant differences between treatments were found in absolute and relative (to the maximum) gs, but a gs decrease was shown in all treatments towards the end of the experiment (Fig. 6. panel E).

The $\Psi_{\text {osmotic }}$ in leaf tissue was significantly lower in $\mathrm{HeL}(-2.1 \pm 0.2 \mathrm{MPa})$ and Ho $(-1.97 \pm 0.15 \mathrm{MPa})$ compared to $\mathrm{C}(-1.6 \pm 0.17 \mathrm{MPa})(P=0.05)$, whereas in $\mathrm{HeU}(-1.9 \pm 0.1 \mathrm{MPa})$ plants presented an intermediate value undifferentiated of $\mathrm{C}$.

In reference to the concentration of ions present in leaf tissue, in Eucalyptus sp., the ion $\mathrm{Cl}^{-}$was higher in $\mathrm{HeU}$ and Ho treatments compared to $\mathrm{C}$, with no differences between them (Table 2). Another anion involved in osmotic adjustment that showed differences between treatments was $\mathrm{F}^{-}$, whose concentration was significantly lower in Ho with respect to HeL, although not different from $\mathrm{HeU}$ and $\mathrm{C}$ (Table 2). A higher concentration 


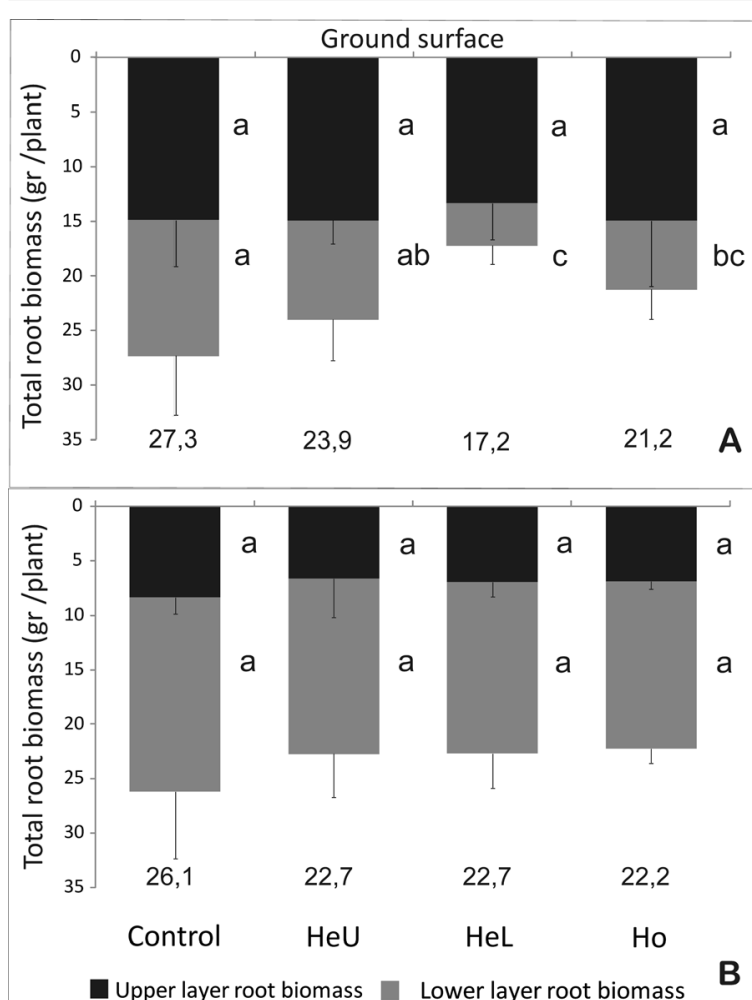

Fig. 4 Total root biomass in each soil layer, upper and lower layer. Panel a Eucalyptus camaldulensis Panel b Salix matsudana $x$ S.alba "NZ 26992". C = Control, $\mathrm{HeU}=$ salt gradient with higher $\mathrm{EC}$ in the upper layer, $\mathrm{HeL}=$ salt gradient with higher EC in the lower layer; $H o=$ homogeneous salinity. Values are means $(n=7) \pm$ s.d. Each bar represents different treatment, the letters indicate significant differences between treatments $(P \leq 0.05)$. The numbers below each bar represent the grams of total root biomass for each treatment and species of $\mathrm{NO}_{2}{ }^{-}$was observed in $\mathrm{HeL}$ and $\mathrm{Ho}$ than in $\mathrm{C}$, whereas the $\mathrm{SO}_{4}{ }^{=}$concentration decreased in $\mathrm{HeL}$ and Ho treatments compared with $\mathrm{C}$.

Regarding the cations, compared with $\mathrm{C}$, the $\mathrm{Ca}^{+2}$ content was $30 \%$ higher in the HeU treatment ( $p$ value $=0.05$ ). In HeL and Ho treatments, although having not shown statistical differences with $\mathrm{C}$, also showed a higher concentration of $\mathrm{Ca}^{+2}$, by $23 \%$ and $14 \%$, respectively. Contrary to expectations, no differences were observed between treatments in $\mathrm{Na}^{+}, \mathrm{K}^{+}$and $\mathrm{Mg}^{+2}$ leaf content, and their ratios (Table 2).

Morpho-physiological response of Salix sp. to salinity gradients

Significant differences were observed in total plant biomass between some treatments, in the following order $(p<0.05): \mathrm{C} \geq \mathrm{HeU} \geq \mathrm{Ho} \geq \mathrm{HeL}(\mathrm{C}=81.46 \pm 8.3$ g per plant; $\mathrm{HeU}=80 \pm 11.4 \mathrm{~g}$ per plant; $\mathrm{Ho}=72.1 \pm 12.2 \mathrm{~g}$ per plant; $\mathrm{HeL}=66.5 \pm 9.8 \mathrm{~g}$ per plant). The shoot biomass $(\mathrm{ShB})$ followed the same trend. Differences between treatments in $\mathrm{ShB}$ were explained by differences in total leaf biomass and not by differences in stem biomass, which were similar between treatments (data not shown). The $0 \%$ leaf damaged was significantly higher in $\mathrm{C}$ and decreased by $16 \%, 27 \%$ and $25 \%$ respectively in HeU, HeL and Ho (Fig. 3, panel B). The 1$50 \%$ leaf damaged was significant higher in HeL and Ho respect to Control, while 50-100\% leaf damaged was similar between treatments. The relationship 0\% leaf
Fig. 5 Relative volumetric growth to the initial value (proportion) of Salix matsudanax alba "NZ 26992" and Eucalyptus camaldulensis. Control (C), salt gradient with higher electrical conductivity (EC) in the upper layer $(\mathrm{HeU})$, salt gradient with higher EC in the lower layer (HeL) and homogeneous salinity (Ho). Values are means $(n=7) \pm$ s.d. Different letters indicate significant differences between treatments $(P \leq 0.05)$

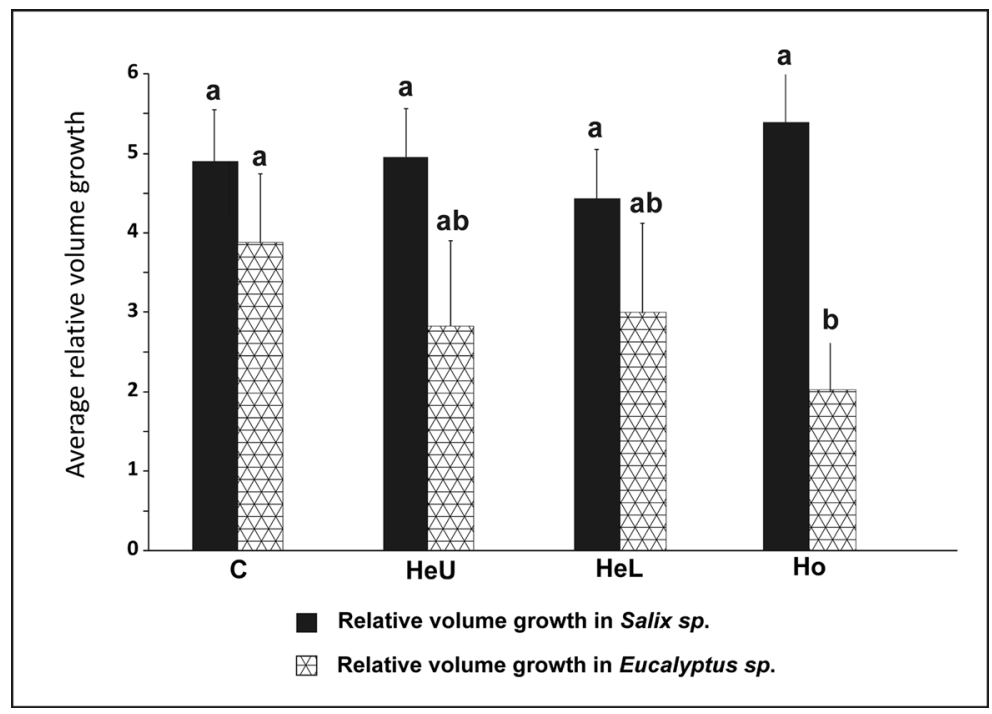



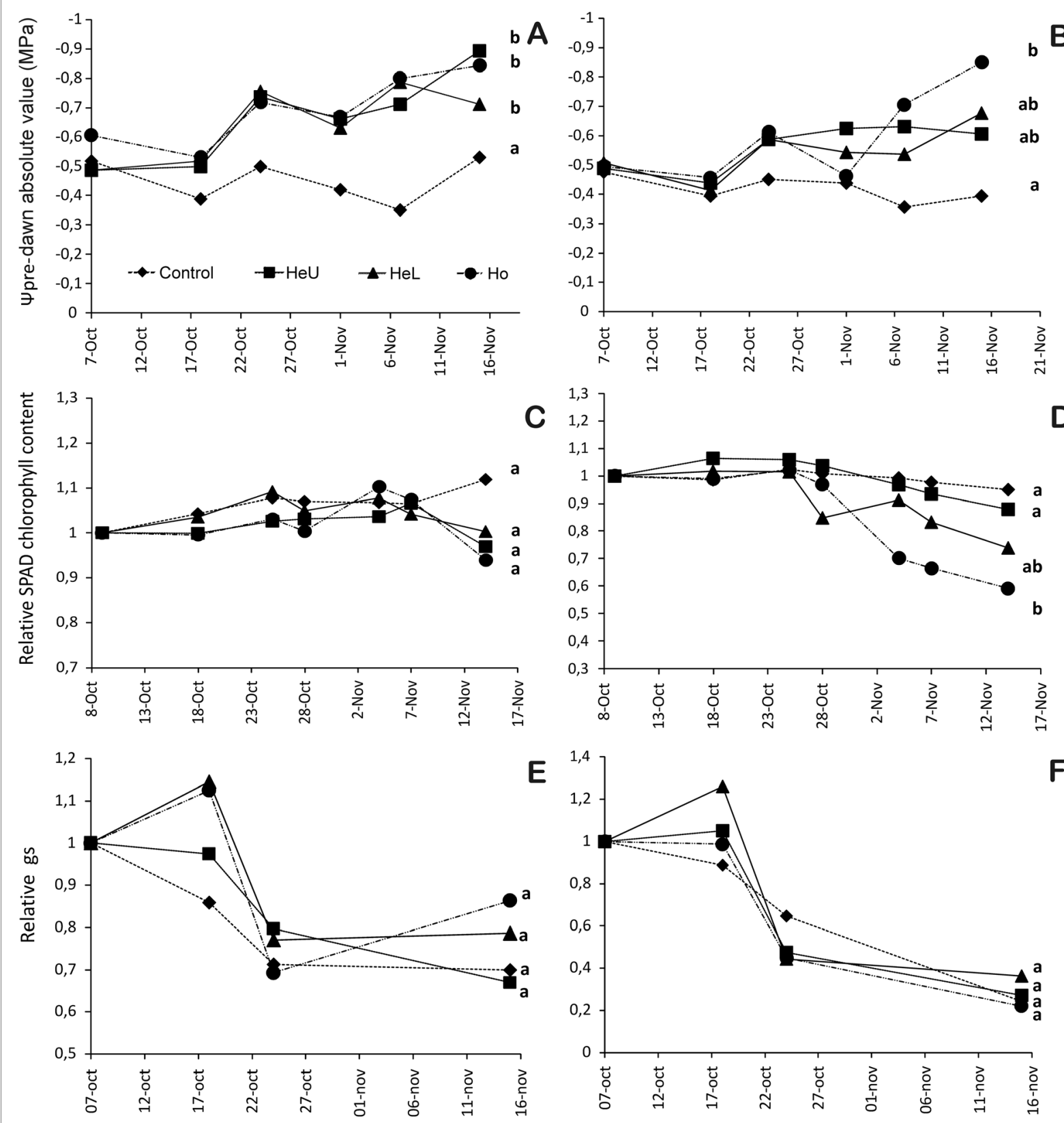

Fig. 6 Pre-dawn water potential $\left(\Psi_{\text {pre-dawn }}\right)$ absolute value in $\mathrm{MPa}$, Relative (value in each date over value at the initial date) of SPAD chlorophyll content and stomatal conductance (gs) measured in Eucalyptus camaldulensis (a, c and e) and Salix matsudana x alba "NZ 26992". (b, d, and f) growing in four

damaged/total leaf biomass also showed differences between treatments $(\mathrm{C} \geq \mathrm{HeU} \geq \mathrm{HeL}=\mathrm{Ho})$. The ratio $1-$ $50 \%$ leaf damaged/total leaf biomass showed differences between $\mathrm{C}$ and all of the saline treatments $(\mathrm{C}$ treatments: Control (C), salt gradient with higher electrical conductivity (EC) in the upper layer (HeU), salt gradient with higher $\mathrm{EC}$ in the lower layer (HeL) and homogeneous salinity (Ho). Different letters indicate significant differences $(P \leq 0.05)$ between treatments (repeater measures ANOVA) within each species

$\mathrm{Ho}=\mathrm{HeL}=\mathrm{HeU})$. The rising of partially damaged leaves biomass with respect to $\mathrm{C}$ was by $16 \%, 52 \%$ and $50 \%$ in $\mathrm{HeU}, \mathrm{HeL}$ and $\mathrm{Ho}$, respectively. Finally, the ratio 50-100\% leaf damaged/total leaf biomass, total root 
Table 2 Ions concentration (nM/mg) in leaf tissue of plants of Eucalyptus camaldulensis (Eucalyptus sp.) and $S$. matsudana $x$ S.alba "NZ 26992" (Salix sp.) grown in four treatments: Control
(C), salt gradient with higher electrical conductivity (EC) in the upper layer (HeU), salt gradient with higher EC in the lower layer (HeL) and homogeneous moderate salinity (Ho)

\begin{tabular}{|c|c|c|c|c|c|c|c|c|}
\hline \multirow{2}{*}{$\begin{array}{l}\text { Ions } \\
\text { (nanoM/mg) }\end{array}$} & \multicolumn{4}{|l|}{ Eucalyptus sp. } & \multicolumn{4}{|l|}{ Salix sp. } \\
\hline & $\mathrm{C}$ & $\mathrm{HeU}$ & $\mathrm{HeL}$ & Ho & $\mathrm{C}$ & $\mathrm{HeU}$ & $\mathrm{HeL}$ & Ho \\
\hline $\mathrm{F}^{-}$ & $56 \pm 7 \mathrm{ab}$ & $58 \pm 10 \mathrm{ab}$ & $66 \pm 9 b$ & $50 \pm 14 \mathrm{a}$ & $83 \pm 13 a$ & $79 \pm 4 \mathrm{a}$ & $66 \pm 11 \mathrm{a}$ & $73 \pm 7 a$ \\
\hline $\mathrm{Cl}^{-}$ & $57 \pm 28 \mathrm{a}$ & $122 \pm 41 \mathrm{ab}$ & $147 \pm 28 b$ & $138 \pm 1 b$ & $35.5 \pm 7 \mathrm{a}$ & $215 \pm 32 b$ & $298 \pm 19 \mathrm{c}$ & $369 \pm 10 \mathrm{~d}$ \\
\hline $\mathrm{NO}_{2}^{-}$ & $0.34 \pm 0.05 \mathrm{a}$ & $0.4 \pm 0.04 \mathrm{ab}$ & $0.44 \pm 0.04 b$ & $0.44 \pm 0.04 b$ & $0.52 \pm 0.06 \mathrm{a}$ & $0.52 \pm 0.01 \mathrm{a}$ & $0.48 \pm 0.03 \mathrm{ab}$ & $0.43 \pm 0.02 b$ \\
\hline $\mathrm{PO}_{4}=$ & $49 \pm 12 \mathrm{a}$ & $34 \pm 15 \mathrm{a}$ & $28 \pm 10 \mathrm{a}$ & $31 \pm 19 \mathrm{a}$ & $29 \pm 9 \mathrm{a}$ & $23 \pm 3 \mathrm{a}$ & $27 \pm 4 \mathrm{a}$ & $32 \pm 5 \mathrm{a}$ \\
\hline $\mathrm{SO}_{4}=$ & $7 \pm 1 \mathrm{a}$ & $4.5 \pm 1 \mathrm{~b}$ & $3.4 \pm 0.5 \mathrm{~b}$ & $4 \pm 1,8 b$ & $90 \pm 19 \mathrm{a}$ & $92 \pm 21 \mathrm{a}$ & $84 \pm 14 a$ & $89 \pm 12 a$ \\
\hline $\mathrm{Na}^{+}$ & $158 \pm 61 \mathrm{a}$ & $190 \pm 59 \mathrm{a}$ & $173 \pm 59 \mathrm{a}$ & $201 \pm 35 \mathrm{a}$ & $20 \pm 5,4 \mathrm{a}$ & $23 \pm 6 a$ & $20 \pm 5 \mathrm{a}$ & $23 \pm 4 \mathrm{a}$ \\
\hline $\mathrm{K}^{+}$ & $220 \pm 10 a$ & $210 \pm 38 \mathrm{a}$ & $223 \pm 29 a$ & $192 \pm 10 \mathrm{a}$ & $655 \pm 102 \mathrm{a}$ & $622 \pm 94 \mathrm{a}$ & $558 \pm 57 \mathrm{a}$ & $561 \pm 19 a$ \\
\hline $\mathrm{Mg}^{+2}$ & $66 \pm 15 \mathrm{a}$ & $58 \pm 13 \mathrm{a}$ & $66 \pm 11 \mathrm{a}$ & $63 \pm 13 a$ & $113 \pm 29 a$ & $152 \pm 35 \mathrm{~b}$ & $123 \pm 6 \mathrm{ab}$ & $139 \pm 15 \mathrm{ab}$ \\
\hline $\mathrm{Ca}^{+2}$ & $21 \pm 2 \mathrm{a}$ & $27 \pm 5 \mathrm{~b}$ & $26 \pm 4 \mathrm{ab}$ & $24 \pm 2 \mathrm{ab}$ & $240 \pm 60 a$ & $312 \pm 72 \mathrm{a}$ & $248 \pm 28 \mathrm{a}$ & $301 \pm 25 \mathrm{a}$ \\
\hline
\end{tabular}

Values are means \pm s.d., $n=4$. Different letters in adjacent columns corresponding to each species indicate significant differences between treatments $(P \leq 0.05)$

biomass/total biomass, upper root biomass/total root biomass and lower root biomass/total root biomass did not show significant differences between treatments.

In contrast to what was observed in Eucalyptus sp. (i.e. significant species $\mathrm{x}$ treatment interaction, $p<0.05$ ), in Salix sp. no effect of soil salinity was observed on biomass root allocation (Fig. 4 panel B). Similarly, no differences in RVG (Fig. 5) nor in the cutting growth diameter (proportion to the initial value) were observed between treatments (Control $=0.17 \pm 0.03$; $\mathrm{HeU}=0.13 \pm 0.03 ; \mathrm{HeL}=0.12 \pm 0.03$; Ho $=0.19 \pm 0.03$ ). Leaf length did also not present differences between heterogeneous or homogeneous salinity treatments and the control, the means and standard deviation of the treatments were Control $=12.07 \mathrm{~cm} \pm 2.3$; $\mathrm{HeU}=13.04 \mathrm{~cm} \pm 0.6 ; \mathrm{HeL}=12.33 \mathrm{~cm} \pm 1.8$ and $\mathrm{Ho}=12.4 \mathrm{~cm} \pm 0.7$.

Regarding physiological variables, the mean absolute value of $\Psi_{\text {pre-dawn }}$ showed differences $(p<0.05)$ between saline treatments $(\mathrm{Ho}=-0.57 \pm 0.12 \mathrm{MPa}$; $\mathrm{HeU}=-0.54 \pm 0.1 \mathrm{MPa}$; Ho $=-0.51 \pm 0.09 \mathrm{MPa})$ compared with $\mathrm{C}(-0.42 \pm 0.07 \mathrm{MPa})$, and also Ho was different than both $\mathrm{HeU}$ and HeL (Fig. 6. Panel B for values in each date). The relative $\Psi_{\text {pre-dawn }}$ to the initial value also showed that all three salinity treatments differed from $\mathrm{C}$, and that Ho presented a higher decrease in water potential, relative to initial values, than $\mathrm{HeL}$, with $\mathrm{HeU}$ between both.

The relative chlorophyll content estimated with SPAD was lower in Ho compared to $\mathrm{C}, \mathrm{HeU}$ and $\mathrm{HeL}$
(Fig. 6. Panel D). Treatments with heterogeneous salinity showed a decrease in chlorophyll content but did not differ from the control. In Salix sp., no significant differences in the absolute $\mathrm{Fv} / \mathrm{fm}$ ratio were observed between treatments. As in Eucalyptus sp., the mean of all treatments gave values close to 0.8 , demonstrating a good state of Photosystem II in the measured leaves $(\mathrm{C}=0.83 \pm 0.03 ; \mathrm{HeU}=0.80 \pm 0.07$; $\mathrm{HeL}=0.81 \pm 0.04 ; \mathrm{Ho}=0.81 \pm 0.04)$. Similarly, no significant differences were found in absolute or relative gs between treatments (Fig. 6. Panel F) nor in $\Psi_{\text {osmotic }}$ (mean value for all treatments: - $1.97 \pm 0.14 \mathrm{MPa}$ ).

Regarding leaf ion content, $\mathrm{Cl}^{-}$concentration highly increased in saline treatments relative to the $\mathrm{C}$ (Table 2). Compared to the $\mathrm{C}$, plants growing in the homogeneous soil salinity treatment had $\mathrm{Cl}^{-}$concentration 10-fold higher, whereas $\mathrm{HeU}$ and $\mathrm{HeL}$ also showed significant differences, being 6 and 8-fold higher than $\mathrm{C}$, respectively (Table 2). Treatment Ho showed a lower concentration of $\mathrm{NO}_{2}{ }^{-}$with respect to Control (Table 2). No significant differences between treatments were observed in $\mathrm{F}^{-}, \mathrm{PO}_{4}=$ and $\mathrm{SO}_{4}=$ concentrations (Table 2). Plants from treatment $\mathrm{HeU}$ increased by $35 \%$ their leaf $\mathrm{Mg}^{+2}$ concentration with respect to $\mathrm{C}$ ( $p$ value $<0.05$ ), and no significant differences with respect to the control were observed in HeL and Ho (Table 2). Contrary to expectations, no differences between treatments in the $\mathrm{Na}^{+}, \mathrm{K}^{+}$and $\mathrm{Ca}^{+2}$ concentration were observed nor in their ratios $\left(\mathrm{Ca}_{2}{ }^{+} /\right.$ $\mathrm{Na}^{+}, \mathrm{Mg}_{2}{ }^{+} / \mathrm{Na}^{+}$and $\mathrm{K}^{+} / \mathrm{Na}^{+}$). 


\section{Discussion}

In this study it was assessed how growth and physiology of the hybrid clone Salix matsudana x alba "NZ 26992" (Salix sp.) and Eucalyptus camaldulensis (Eucalyptus $s p$.), two glycophyte species with different root system and stress tolerance, respond to salinity arranged in different vertical gradients. Four alternative hypotheses were evaluated, suggesting that growth and physiology are determined either by: $\mathrm{H} 1$ ) the average salinity of the rhizosphere, H2) the average salinity of the rhizosphere weighted by the number of roots in each portion of the soil, H3) the less saline portion of the soil, or H4) the most saline portion of the soil.

Therefore, if growth and physiology of both species respond to $\mathrm{H} 1$, the expected relationship between treatments would be $\mathrm{HeU}=\mathrm{HeS}=\mathrm{Ho} \quad \mathrm{C}$, because if the plants averaged the salt present in the soil, there would be no difference between saline treatments. If instead plants respond to average salinity weighted by the number of roots in each portion of the soil, in Eucalyptus sp., given its tap root system, it is expected most of the woody root biomass to be in the upper layer, so the relationship between treatments would be as follows $\mathrm{C}>\mathrm{HeL}>\mathrm{Ho}>\mathrm{HeU}$. Typically there are more roots in the upper than in lower parts of the soil profile (Schenk and Jackson 2002), however since Salix spp. cuttings generate adventitious roots, they should produce roots more or less evenly distributed throughout the soil profile, being the expected response of treatments: $\mathrm{C}>\mathrm{HeU} \geq \mathrm{HeL}=\mathrm{Ho}$. If the plants respond to the most saline portion soil (H4), the expected relationship between treatments in both species would be $\mathrm{C}>\mathrm{Ho}>\mathrm{HeU}=\mathrm{HeL}$, while if they respond to the less saline portion $(\mathrm{H} 3)$, the expected response in both species would be $\mathrm{C} \geq \mathrm{HeU}=\mathrm{HeL}>\mathrm{Ho}$. In this case the homogeneous salinity treatment would be the most affected, as there is no possible escape from salts in any of the soil layer.

Effect of vertical salinity gradients in a glycophyte species with tap root system and moderate to high salinity tolerance

In Eucalyptus camaldulensis there were no significant differences in total biomass production between treatments. However, under conditions of homogeneously distributed moderate salinity (Ho) the pattern of leaf senescence was more pronounced, which was accompanied by a decrease in the stem relative volume growth (RVG) of 50\% compared with the control. At the same time, in the heterogeneously distributed salinity treatments the RVG was slightly lower and the leaf senescence somewhat higher, but with no significant differences respect to the control. These results provide evidence in favor of $\mathrm{H} 3$ for E. camaldulensis. At the same time, this is consistent with the results obtained by Bingham and Garber (1970) evaluating the growth of the stem in sweet corn plants subjected to vertical gradients of salinity (only report of this kind of treatment in a glycophyte species), where a 30\% decrease in growth was observed when the entire root system was exposed to salt, whereas when only one third or two thirds of the root system were exposed to salt, the stem growth decreased only by $10 \%$. A similar response was reported in other woody glycophyte species such as Citrus aurantium (Zekri and Parson 1990) and cotton (Kong et al. 2012) growing in split - root systems, which generate heterogeneous salinity conditions but in a horizontal gradient. In these cases a decrease in stem growth by 10-20\% relative to the control was observed when at least part of the root system was exposed to salinity. At the same time, both studies suggest that the presence of salts in at least part of the root system is sufficient to increase the absorption of water by $50 \%$ in the less saline or unsalted site.

Despite this, the total root biomass, an indicator of underground plant growth, showed that the presence of salts in the lower soil layer, i.e. in both HeL and Ho, generates a significant decrease of root biomass respect to control, which meant $70 \%$ and $50 \%$ less roots for $\mathrm{HeL}$ and Ho, respectively. However, in the HeU treatment such response was not observed, being the root biomass in this soil layer similar to the control.

Contrary to the conclusions drawn from the aboveground variables, the results obtained in E. camaldulensis at root level indicate that the underground growth did not respond to any of the hypotheses initially raised. Importantly the root biomass produced in control conditions was similar between soil layers, indicating the proper functioning of the experimental system used and allowing roots to grow throughout the profile of the pot, ensuring a similar salt exposure in both soil layers. Therefore, the decrease in root biomass in the lower layer, both in $\mathrm{HeL}$ and Ho, would indicate two possible responses: the root growth inhibition in this layer in response to salts, or a significant root mortality because of the absorption of salts and their toxic effect in this 
compartment of the plant. In this regard, although it was not possible to measure water consumption in this research, Thorburn and Walker (1994), using $\mathrm{H}^{2}$ and $\mathrm{O}^{18}$ isotopes in field conditions, determined that E. camaldulensis, even growing near $(30 \mathrm{~m})$ to fresh water stream and with surface fresh water availability $(0.05-0.15 \mathrm{~m})$, continued uptaking groundwater with high salt concentration $(40 \mathrm{dS} / \mathrm{m})$. This meant about $30 \%$ of the water present in the branches of the trees. This phenomenon was at the expense of reducing the $\Psi_{\text {pre -dawn }}$ and the plant hydric status. This information, along with the one suggested by Bazihizina et al. (2012a) for salinity tolerant species, proposing that under heterogeneous salinity (either horizontal or vertically) tolerant species may uptake water in the saline area, and this would account for 9 to $30 \%$ of the total water consumed, allowed to raise a new prediction in this work expected if the $\mathrm{H} 2$ is true. In this regard, given the adaptive behavior of E. camaldulensis that allows greater water uptake in lower soil areas (even under conditions of high salinity in the groundwater), it is expected that if the plants respond to the average salinity of the root zone weighted by the increased absorption of salts in the lower layer, the treatments in this work will present the following relationship $\mathrm{C} \geq \mathrm{HeU}>\mathrm{Ho} \geq \mathrm{HeL}$. That is, the most affected treatments would be HeL and Ho, where plants could not escape the absorption of salts, and HeL would be more affected than Ho due to higher salt concentration in the lower layer. Given this consideration in $\mathrm{H} 2$, which means a higher absorption in the lower layer than in the upper, the results of root growth of this species under vertical salinity gradients indicate that it would respond to the average salinity of the rhizosphere weighted by the number of roots and their absorption capacity in each soil layer.

On the other hand, these results of E. camaldulensis growing in vertical salinity gradients provide evidence in favor of Bazihizina et al. (2012a) hypothesis suggesting that phreatophyte genotypes growing in a vertically heterogeneous salinity gradient with high superficial salinity, would be able to explore deep layers in search of less saline conditions that will maintain the stem growth avoiding the negative impact of salts on it, which has been demonstrated in this work by the results obtained in the $\mathrm{HeU}$ treatment. At the same time, saline conditions (high or moderate) in deep soil horizons would generate a significant decrease in root growth as a strategy of acclimation. Thus, although aboveground tolerance mechanisms are observed in HeL, the reduction of root biomass in saline horizons, particularly when salt is in lower soil layers, suggest an avoidant mechanism based on a low generation of deep roots. This response may have no effect, or a moderate one, on the stem growth under heterogeneous conditions of salinity that make possible an escape from salts by the absorption in less saline sites, but would result in a significant decline of the stem growth when there are no possibilities of escape from salts as occurs under homogeneous conditions of salinity, even in a low concentration.

In turn, from a physiological point of view, the $\mathrm{HeL}$ and $\mathrm{HeU}$ treatments showed no effect of salts on the chlorophyll content estimated with SPAD, stomatal conductance (gs) and the integrity of PSII (Fv/fm). These results contrast with previous studies in this species, in which a decrease in gs (Marcar et al. 2002), a degradation of chlorophyll by a $20 \%$ and a decrease in $\mathrm{Fv} / \mathrm{fm}$ respect to Control under similar concentrations of $\mathrm{NaCl}$ to those evaluated in this work (Cha-um and Kirdmanee 2010) were observed. However, other physiological parameters as $\Psi_{\text {pre-dawn }}, \Psi_{\text {osm }}$, or ions concentrations in leaves were affected as a result of exposure to vertical salinity gradients.

The $\Psi_{\text {pre-dawn }}$ showed a response similar to what was stated in the H1, indicating that this variable responds to the average salinity of the rhizosphere, which is expected if the water status of the plant responds to water uptake from both layers, and this absorption is not inhibited even under high salinity in any soil layer. This effect on the $\Psi_{\text {pre-dawn }}$ generated by the water uptake from different parts of the soil has been demonstrated for this species in field experiments with isotopes $\mathrm{H}^{2}$ and $\mathrm{O}^{18}$ (Thorburn and Walker 1994; Mensforth et al. 1994).

However, the $\Psi_{\text {osmotic }}$ and $\mathrm{Cl}^{-}$concentration in leaves, variables related to salts uptake and tolerance degree in various species, showed differences between HeL and Ho treatments compared to Control, behaving as predicted in $\mathrm{H} 2$, (assuming that this species always tends to take water from deep horizons). Also, results of EC (1:2.5) measurements in soil samples of the different layers obtained at the end of the experiment, support this conclusion since in $\mathrm{HeU}$ and Ho treatments the EC of upper layer was close to the EC values of the irrigation solution, while the EC in the lower layer was lower than the expected, suggesting that the plants have taken the salts from it. 
The increase in the $\mathrm{Cl}^{-}$concentration in leaves both in $\mathrm{Ho}$ and $\mathrm{HeL}$ coincides with the results obtained by Nasim et al. (2009), working with two genotypes of E. camaldulensis exposed to a higher salinity concentration than the assessed here $(13.7 \mathrm{dS} / \mathrm{m})$ which was homogeneously distributed and applied for 8 weeks. In this case, the $\mathrm{Cl}^{-}$concentration increased 3 and 2 times relative to the control. That result was accompanied by an increase in the concentration of $\mathrm{Na}^{+}$(3-fold than the C) and a decrease in $\mathrm{K}^{+}$in both genotypes. Similarly, Isla et al. (2014), working with a homogeneous $\mathrm{NaCl}$ concentration $(7 \mathrm{dS} / \mathrm{m})$, a value close to that used in the present study, also reported for this species a three-fold increase in $\mathrm{Cl}^{-}$concentration in leaves compared to the control and, contrary to us, a similar increase in the concentration of $\mathrm{Na}^{+}$. At the same time, and also unlike our results, they found a slight decrease in $\mathrm{Ca}^{+2}$ content of the leaves. Isla et al. (2014) also evaluated the content of these ions at root level and they found no increase in $\mathrm{Cl}^{-}$and $\mathrm{Na}^{+}$concentration in comparison to the control. Differences between studies suggest that exposure to similar concentrations of $\mathrm{NaCl}$, but arranged in a vertical gradient, affecting part of the root system more than another (the present study) allows a better acclimation to saline stress that prevents increased levels of $\mathrm{Na}^{+}$at leaf level, a highly damaging phenomenon for cell homeostasis.

It is also interesting to note the results obtained in the $\mathrm{K}^{+}$levels in leaf tissue, which showed no significant differences between treatments, as was also the case of the ionic ratios $\mathrm{K}^{+} / \mathrm{Na}^{+}, \mathrm{Mg}_{2}{ }^{+} / \mathrm{Na}^{+}$and $\mathrm{Ca}^{+} / \mathrm{Na}^{+}$. These results agree with those obtained by Isla et al. (2014) and contradict those reported by Van der Moezel et al. (1989), who describe a significant decrease in the content of $\mathrm{K}^{+}$in the E. camaldulensis stem. The relationship between the exclusion of leaf $\mathrm{Na}^{+}$and $\mathrm{Cl}^{-}$and salt tolerance of $E$. camaldulensis was raised by Isla et al. (2014) and Van der Moezel et al. (1989). This exclusion mechanism is particularly important in perennial plants where exposure to salts in the long term may exacerbate the toxic accumulation of these ions by leaf transpiration (Munns and Tester 2008). The response observed in the genotypes of E. camaldulensis evaluated in this study indicates a significant compartmentalization or exclusion of $\mathrm{Na}^{+}$and $\mathrm{Cl}^{-}$ions at root level, a tolerance mechanism to salts proposed by Jobbagy and Jackson (2004) through the field evaluation of genotypes of the same species implanted in Argentina.
Other phenomena observed with heterogeneous salinity in the soil cannot be completely discarded. In this regard, Kong et al. (2012) determined a low concentration of $\mathrm{Na}^{+}$ions in leaf tissue of cotton plants treated with split-root systems, which was accompanied by an increase in the concentration of $\mathrm{Na}^{+}$ions in the low salinity compartments. The authors attributed this finding to a flow of ions from the leaves to the roots through the phloem. Based on these results, and the ability of this species for water redistribution through their root system (Burgess et al. 1998), it would be interesting to investigate whether a similar mechanism is possible in E. camaldulensis under vertically heterogeneous salinity. If so it would be possible to explain the lack of accumulation of $\mathrm{Na}^{+}$and decreased $\mathrm{K}^{+}$in the leaf observed in this work, while would justify the slight increase in EC in lower saline layer of the pot in $\mathrm{HeU}$ treatment respect to Control, which generated the loss of the salinity gradient at the end of the experiment both in E. camaldulensis and Salix sp. Therefore, we consider necessary new studies to investigate this issue.

Simultaneously, the cations profile in E. camaldulensis detected an increase in $\mathrm{Ca}^{+2}$ in $\mathrm{HeU}$ compared to the Control, accompanied by a lower impact of the salts on the aboveground and root growth. HeL and Ho treatments showed no difference in the content of $\mathrm{Ca}^{+2}$ with respect to $\mathrm{C}$ and showed a higher saline impact on growth. This relation between treatments did not respond to any of the hypotheses and contradicts other results obtained for this ion in leaf tissue of E. camaldulensis subjected to salinity (Isla et al. 2014). The increase in cytosolic $\mathrm{Ca}^{+2}$ has been reported as an early cellular signal of tolerance to salt stress (Pandey et al. 2004), which protects the cell from harmful effects of salts (Martinoia et al. 2012; Wolf et al. 2012). For this reason, more specific studies are needed to determine if a similar response between treatments is seen at the root level and if higher $\mathrm{Ca}^{+2}$ leaf concentration in $\mathrm{HeU}$ treatment in E. camaldulensis is actually reflecting a greater tolerance to salinity stress when salts are located in upper soil layer compared to an inverse gradient.

Effect of vertical salinity gradients in a glycophyte species with adventitious and shallow root system and low or moderate tolerance to salinity

In Salix matsudana $x$ S. alba, root biomass obtained at the end of the experiment was higher in the lower soil layer $(70 \%)$ than in the upper in all treatments, 
indicating an unequal distribution of roots in the soil profile. Therefore, the prediction of $\mathrm{H} 2$ was corrected based on these results, expecting a higher effect in plants, both in physiological and growth parameters, when the salinity is in the lower layer (i.e. where there are more roots), and the concentration of salts is higher. Thus, if $\mathrm{H} 2$ were true, growth and biomass production in these treatments would respond to the following relation: $\mathrm{C}>\mathrm{HeU}>\mathrm{Ho} \geq \mathrm{HeL}$.

While at root level there was no response of plants in this regard, since no differences were found between treatments in total root biomass or by soil layer, both total biomass and total aerial biomass are in agreement with H2. In turn, in the aerial biomass, the leaf component was the most affected, because $0 \%$ damaged leaf biomass was lower in Ho and HeL treatments compared to the control, and $1-50 \%$ damaged leaf biomass was higher in the same treatments (Fig. 3, panel b). All salinity treatments showed effects on leaf senescence, although the highest impact was observed in Ho and $\mathrm{HeL}$, demonstrating again most importantly the location of salts in the soil profile than the concentration per se. At the same time, the stem growth in this species was not affected by homogeneous or heterogeneous salinity, consistent with the results obtained at root level.

From a physiological point of view, in Salix sp., the $\Psi_{\text {pre -dawn }}$ and chlorophyll content estimated with SPAD differed between treatments. Both variables were affected in plants exposed to vertical gradients of salt and they would respond to the less saline portion of the soil (H3), as treatments with heterogeneous salinity in which plants can access a less saline portion of root zone were the least affected. On the other hand, although the $\Psi_{\text {osmotic }}$ showed no differences between treatments, suggesting no osmotic adjustment in the species in response to salinity, some ions concentrations in leaves were affected. $\mathrm{Cl}^{-}$and $\mathrm{Mg}^{+2}$ were the most important affected ions in cellular homeostasis. The homogeneous salinity treatment showed a higher $\mathrm{Cl}^{-}$concentration relative to the control (10 times), while heterogeneous salinity treatments showed $\mathrm{Cl}^{-}$concentration higher than control but lower than Ho. The $\mathrm{Cl}^{-}$accumulation indicated an important toxic effect of salts under uniform salinity, even higher than in heterogeneous salinity, which responds to our $\mathrm{H} 3$. In addition, the higher $\mathrm{Cl}^{-}$leaf concentration in $\mathrm{HeL}$ than in $\mathrm{HeU}$ may be explained by higher proportion of roots in the lower soil layer, which improved the growth conditions in $\mathrm{HeU}$ treatment due to lower salt absorption. The higher EC (1:2.5) in the upper soil layer observed in $\mathrm{HeU}$ at the end of the experiment reinforces this conclusion. At the same time, no significant differences between treatments in $\mathrm{Ca}^{+2}$, $\mathrm{K}^{+}$or $\mathrm{Na}^{+}$leaf concentrations or their ionic relationship were obtained.

Some researchers have reported in Populus sp., another genus of Salicaceae family, a salt tolerance response dependent on the ability to restrict the salts passage from roots to stem and leaves, being more tolerant those genotypes capable of presenting low $\mathrm{Na}^{+}$concentration in the stem (Fung et al. 1998; Chen et al. 2002; Isla et al. 2014). Zalesny et al. (2008), working on eight genotypes of Populus spp. irrigated with saline water, indicated an increase of $\mathrm{Cl}^{-}$concentration in leaves and $\mathrm{Na}^{+}$concentration in the roots, along with an increase in leaf senescence and abscission. In some clones, these results were not accompanied by a decrease in growth and biomass production. The response to saline stress in these clones was attributed to a greater compartmentalization of $\mathrm{Cl}^{-}$ions in leaves and new leaf biomass generation that could compensate the toxic effects of salts guaranteeing carbon fixation needed to maintain growth. These results agree with those obtained in this work for Salix sp. cuttings growing under homogeneous salinity conditions. So, is possible to hypothesize on a tolerance mechanism based in $\mathrm{Cl}^{-}$accumulation in the vacuole, in order to avoid the deleterious effects of the salts on the cellular metabolism and carbon fixation. In this regard, gs and PSII status were not affected in photosynthetically active leaves, nor was stem growth and root biomass (at least during 40 days of exposure to salt of this study). It is interesting to investigate whether Salix sp., like Populus sp., responds to salt stress accumulating $\mathrm{Na}^{+}$ions in the roots, and whether longer stress periods can be tolerated without a significant decrease in growth.

On the other hand, the response of Salix sp. to vertical salinity gradients suggests that, under this condition, the tolerance threshold for salt concentration can be further extended due to certain physiological variables such as $\Psi_{\text {pre -dawn, }}$ chlorophyll content measured with SPAD and leaf $\mathrm{Cl}^{-}$concentration responded to the less saline portion of the soil. These results also suggest that under heterogeneous salinity conditions salt-avoiding strategy is possible more than its tolerance. In this sense, the resistance of saline stress developed by Salix sp. would be based on the loss of foliar biomass, similar to what happens under drought stress (e.g. Bonosi et al. 2010; Doffo et al. 2017), but in the case of salinity, this 
mechanism would allow it to remove toxic ions accumulated in leaf tissue. Remaining leaves could therefore maintain their water status and $\mathrm{C}$ fixation capacity needed for growth. It is expected that. When environmental conditions are more favorable, the ability to maintain the good water status of the plant and a low toxicity due to the compartmentalization of ions, would eventually allow this species a rapid regeneration of foliage in order to continue the growth. This mechanism would be useful in environments with moderate and sporadic salinity (e.g. salinity pulses due to the rise of a saline water table, and / or concentration of salts on the surface by high evaporation in a drought period which are washed with precipitation events), but would not allow it, however, to grow in permanent salinity conditions.

\section{Conclusion}

The results of this study indicate that Eucalyptus camaldulensis growing in vertical gradients of soil salinity would present leaf tolerance mechanisms, through osmotic adjustment (mainly in treatments with salt in the lower soil layer), related or not to $\mathrm{Cl}^{-}$accumulation, allowing it to maintain leaf functioning. At the same time, it presents an avoidance strategy at root level, due to lower root growth in saline soil layers when they are in lower positions of the soil profile, and potentially, $\mathrm{Na}^{+}$ exclusion. As a result of these resistance mechanisms, aerial growth is less compromised, responding as a function of the less saline soil portion. On the other hand, the direction of the salinity gradient had an effect on the observed responses, being less affected when salts are located in higher compared to lower soil layers.

By contrast, Salix matsudana $x$ S. alba showed a salinity response characterized by senescence and decrease of green leaf biomass. This strategy was mainly seen in treatments with homogeneous salinity along the soil profile or with salt restricted to lower soil layers. The loss of leaves was the result of compartmentalization of $\mathrm{Cl}^{-}$in some of them, while undamaged leaf biomass maintained its functionality. Likewise, this "forced" reduction of the transpiration surface - decreasing subsequent water inflows with salts - could be useful to counteract uptake of salts by the root system maintained in saline soil (root tolerance). As a consequence, plants presented similar stem growth in all treatments, but decreased total biomass (mainly due to leaves) in the above mentioned saline treatments. At least in the short term, this mechanism would allow to maintain similar stem volume growth in plants exposed to vertical gradients of salinity or homogeneous salinity (but in quite low concentration) compared to non- saline soils. However, a reduction in leaf biomass could have implications in future growth, depending on the level of $\mathrm{C}$ reserves and the duration of the exposure to salts.

As a whole, our results show that the response of Eucalyptus camaldulensis and Salix matsudana $x S$. alba to homogeneous conditions of salinity maybe different from than observed when these taxa are facing vertical salinity gradients as given in the field, and even with higher concentrations of $\mathrm{NaCl}$. In this regard, determining tolerance thresholds in both species could vary depending on the salt distribution in the soil. Lower concentrations of salt evenly distributed in the soil profile would have more effect than restricted high salt concentrations; and the impact of high salinity could be higher when it is located in deeper soil layers. These considerations must be taken into account in extrapolation of results from pots to field natural conditions in these species, as well in other woody species.

Acknowledgements We thank Dr. F. Andrade (Crop Ecophysiology Laboratory of INTA EEA Balcarce, Argentina, CONICET Argentina) for his valuable comments on this manuscript, N. Pugliese for helping in the construction of the experimental system, S. Quiñones and A Gago for help during the sampling, and M. Colabelli for her support and advice during different stages of the study. This work is part of the doctoral studies of A.Q.M at the Facultad de Ciencias Agrarias, Universidad Nacional de Mar del Plata (Argentina), supported by a fellowship of the National Council of Scientific and Technological Research (CONICET, Argentina).

\section{Compliance with ethical standards}

Conflict of interest None declared.

Funding This work was funded by grants 300511-UCAR (Unidad Para el Cambio Rural) -MAGyP (Ministerio de Agricultura, Ganadería y Pesca) and PNFOR110473 - INTA (Instituto Nacional de Tecnología Agropecuaria), Argentina.

\section{References}

Argus RE, Colmer TD, Grierson PF (2015) Early physiological flood tolerance is followed by slow post-flooding root recovery in the dryland riparian tree Eucalyptus camaldulensis 
subsp. Refulgens Plant cell Env 38(6):1189-1199. doi: $10.1111 /$ pce. 12473

Bazihizina N, Barrett-Lennard E, Colmer TD (2009) Response to non-uniform salinity in the root zone of the halophyte Atriplex nummularia: growth, photosynthesis, water relations and tissue ion concentrations. Ann Bot 104:737-745

Bazihizina N, Barrett-Lennard E, Colmer TD (2012a) Plant growth and physiology under heterogeneous salinity. Plant Soil 354:1-19

Bazihizina N, Barrett-Lennard E, Colmer TD (2012b) Plant responses to heterogeneous salinity: growth of the halophyte Atriplex nummularia is determined by the root-weighted mean salinity of the root zone. J Exp Bot 63:6347-6358

Bennett SJ, Barrett-Lennard EG, Colmer TD (2009) Salinity and waterlogging as constraints to saltland pasture production: a review. Agr. Ecosyst Environ 129:349-360

Bingham FT, Garber MJ (1970) Zonal salinization of the root system with $\mathrm{NaCl}$ and boron in relation to growth and water uptake of corn plants. Soil Sci Soc Am Proc 34:122-126

Bleby TM, Aucote M, Kennett-Smith AK, Walker GR, Schachtman DP (1997) Seasonal water use characteristics of tall wheatgrass (Agropyron elongatum (host) Beauv) in a saline environment. Plant Cell Environ 20:1361-1371

Bonosi L, Ghelardini L, Weih M (2010) Growth responses of 15 Salix genotypes to temporary water stress are different from the responses to permanent water shortage. Trees 24:843854

Burgess SSO, Adams MA, Turner NC, Ong CHK (1998) The redistribution of soil water by tree root systems. Oecologia 115:306-311

Cha-um S, Kirdmanee C (2010) Effects of water stress induced by sodium chloride and mannitol on proline accumulation, photosynthetic abilities and growth characters of eucalyptus (Eucalyptus Camaldulensis Dehnh.) New For 40:349-360. doi:10.1007/s11056-010-9204-1

Chen SL, Lia JK, Fritz E, Wang SS, Huttermann A (2002) Sodium and chloride distribution in roots and transport in three poplar genotypes under increasing $\mathrm{NaCl}$ stress. For Ecol Manag 168:217-230

Doffo G, Monteoliva SE, Rodríguez ME, Luquez VMC (2017) Physiological responses to alternative flooding and drought stress episodes in two willow (Salix spp.) clones. Can J For Res 47(2):174-182

Dong H, Kong X, Luo Z, Li W, Xin C (2011) Unequal salt distribution in the root zone increases growth and yield of cotton. Eur J Agron 33:285-292

FAO (2011) FAO Landand plant nutrition management service http://www.fao.org/ag/agl/agll/spush

Feikema PM, Sasse JM, Bandara GD (2012) Chloride content and biomass partitioning in eucalyptus hybrids grown on saline sites. New For 43:89-107. doi:10.1007/s11056-011-9268-6

Flores P, Botella MA, Martinez V, Cerda A (2002) Response to salinity of tomato seedlings with a split root system: nitrate uptake and reduction. J Plant Nutr 25:177-187

Flowers TJ, Colmer TD (2008) Salinity tolerance in halophytes. New Phytol 179:945-963

Fung LE, Wang SS, Altman A, Hutterman A (1998) Effect of $\mathrm{NaCl}$ on growth, photosynthesis, ion and water relations of four poplar genotypes. For Ecol Manag 107:135-146
Ghassemi F, Jakeman AJ, Nix HA (1995) Salinization of land and water resources: human causes, extent, management and case studies. University of New South Wales Press Ltd, Canberra

Gomes S, Kozlowski (1980) Effects of flooding on Eucalyptus camaldulensis and Eucalyptus globulus seedlings. Oecologia (Berl) 46:139-142

Hamed KB, Messedi D, Ranieri A, Abdelly C (2008) Diversity in the response of two potential halophytes (Batis maritime and Crithmum maritimum) to salt stress. In: Abdelly C, ztürk M, Ashraf M, Grignon C (eds) Biosaline agriculture and high salinity tolerance. Birkhäuser Verlag AG, Basel, pp 71-80

Hangs RD, Schoenau JJ, Van Rees KCJ, Steppuhn H (2011) Examining the salt tolerance of willow (Salix sp.) bioenergy species for use on salt-affected agricultural lands. Can. J. Plant Sci 91:509-517

Isla R, Guillén M, Aragüés R (2014) Response of five tree species to salinity and waterlogging: shoot and root biomass and relationships with leaf and root ion concentrations. Agrofor Syst 88:461-477. doi:10.1007/s10457-014-9705-6

Ismael A, Takeda S, Nick P (2014) Life and death under salt stress: same players, different timing? J Exp Bot 65:2963-2979

Jobbagy EG, Jackson R (2004) Groundwater use and salinization with grassland afforestation. Glob Chang Biol 10:12991312. doi:10.1111/j.1365-2486.2004.00806.x

Kong X, Luo Z, Dong H, Eneji E, Li W (2012) Effects of nonuniform root zones salinity on water use, $\mathrm{Na}^{+}$recirculation, and $\mathrm{Na}^{+}$and $\mathrm{H}^{+}$flux in cotton. J Exp Bot 63:2105-2116

Koushafara M, Khoshgoftarmanesh AH, Moezzi A, Mobli M (2011) Effect of dynamic unequal distribution of salt in the root environment on performance and Crop Per Drop (CPD) of hydroponic-grown tomato. Sci Hortic 131:1-5

Läuchli A, Epstein E (1990) Plant response to saline and sodic conditions. In: Agricultural Salinity Assessment and Management. Tanji KK (ed). Mannuals and reports on Engineering Practices No 71. Ame Soc. Civ. Engin. New York, 112-137.

Marcar N, Zohar Y, Guo J, Crawford D (2002) Effect of NaCl and high $\mathrm{pH}$ on seedling growth of 15 Eucalyptus camaldulensis Dehnh. Provenances. New For 23:193-206

Martinoia E, Meyer S, De Angeli A, Nagy R (2012) Vacuolar transporters in their physiological context. Annu Rev Plant Biol 63:183-214

Mensforth LJ, Thourburn PJ, Tyerman SD, Walker GR (1994) Sources of water used by riparian Eucalyptus camaldulensis overlying highly saline groundwater. Oecologia 100:21-28

Merchan A, Callister A, Arndt S, Tausz M, Adams M (2007) Contrasting physiological responses of six eucalyptus species to water deficit. Ann Bot 100:1507-1515

Messedi D, Labidi N, Grignon C, Abdelly C (2004) Limits imposed by salt to the growth of the halophyte Sesuvium Portulacastrum. J Plant Nutr Soil Sci 167:720-725

Munns R, Tester M (2008) Mechanisms of salinity tolerance. Annu Rev Plant Physiol 59:651-681

Nasim M, Qureshi RH, Aziz T, Saqib M, Nawaz S, Akhtar J, Haq MA, Talibsahi S (2009) Different eucalyptus species show different mechanisms of tolerance to salinity and salinity $\mathrm{x}$ hypoxia. J Plant Nutr 32:1427-1439

Northey JE, Christen EW, Ayers JE, Jankowski J (2006) Occurrence and measurement of salinity stratification in shallow groundwater in the Murrumbidgee irrigation area, South-Eastern Australia. Agric Water Manag 81:23-40 
Nosetto MD, Jobbágy E, Tóth T, Jackson R (2008) Regional patterns and controls of ecosystem salinization with grassland afforestation along a rainfall gradient. Glob Biogechem Cycles 22:art.no. GB2015

Pandey GK, Cheong YK, Kim KN, Grant JJ, Li LG, Hung W, D'Angelo C, Weini S, Kudla J, Luan S (2004) The calcium sensor calcineurin B-like 9 modulates abscisic acid sensitivity and biosynthesis in Arabidopsis. Plant Cell 16:1912-1924

Pardos JA (2007) Perspectiva fisiológica en la producción y mejora del Eucalipto (con énfasis en Eucalyptus globules Labill). Boletín del CIDEUS 3:7-55

Qiao G, Zhang X, Jiang J, Liu M, Han X, Yang H, Zhuo R (2013) Comparative Proteomic Analysis of Responses to Salt Stress in Chinese Willow (Salix matsudana Koidz). Plant Mol Biol Report. doi:10.1007/s11105-013-0689-6

Quinn LD, Straker KC, Guo J, Kim S, Thapa S, Kling G, Lee DK, Voigt TB (2015) Stress-tolerant feedstocks for sustainable bioenergy production on marginal land. Biol Res 8:10811100. doi:10.1007/s12155-014-9557-y

Quiñones Martorello AS, Fernández ME, Gyenge J, Laclau P, Colabelli M (2012) Rooting of different clones of Salix spp. to multiple stress conditions generated by salinity and anoxia. XXIX RAFV. Bs. As, p 226

Quiñones Martorello AS, Gyenge J, Monterrubianesi G, Fernández ME (2014) Effect of waterlogging-drought sequential multiple stress on morphological and functional characteristics of two clones of Salix spp. and Eucalyptus camaldulensis Dhehn. XXX Latin American Congress of Plant Physiology. MDP. Bs. As., p 149

Robbins CW, Wagenet RJ, Jurinak JJ (1980) A combined salt transport-chemical equilibrium model for calcareous and gypsiferous soil. Soil Sci Soc Am J 44:1191-1194

Schenk HJ, Jackson RB (2002) Rooting depths, lateral root spreads and below-ground/above-ground allometries of plants in water-limited ecosystems. J Ecol 90(3):480-494 DOI:10.1046/j.1365-2745.2002.00682.

Shalhevet J, Bernstein L (1968) Effects of vertically heterogeneous soil salinity on plant growth and water uptake. Soil Sci 106:85-93

Shani U, Waisel Y, Eshel A, Xue S, Ziv G (1993) Responses to salinity of grapevine plants with split root systems. New Phytol 124:695-701

Sixto H, González-Gonzalez BD, Molina-Rueda JJ, GarridoAranda A, Sanchez MM, López G, Gallardo F, Cañuellas I, Mounet F, Grima-Pettenati J, Cantón F (2016) Eucalyptus spp. and Populus spp. coping with salinity stress: an approach on growth, physiological and molecular features in the context of short rotation coppice (SRC). Trees. doi:10.1007 /s00468-016-1420-7

Thorburn PJ, Walker GR (1994) Variations in stream water uptake by Eucalyptus Camaldulensis with differing access to stream water. Oecologia 100:293-301

Van der Moezel PG, Watson LE, Bell DT (1989) Gas exchange responses of two eucalyptus species to salinity and waterlogging. Tree Physiol 5:251-257

Wolf S, Hématy K, Höfte H (2012) Growth control and cell wall signaling in plants. Annu Rev Plant Biol 63:381-407

Woodward AJ, Bennett IJ (2005) The effect of salt stress and abscisic acid on proline production, chlorophyll content and growth of in vitro propagated shoots of Eucalyptus Camaldulensis. Plant Cell Tissue Organ Cult 82:189-200. doi:10.1007/s11240-005-0515-4

Zalesny JA, Zalesny RS Jr, Wiese AH, Sexton B, Hall RB (2008) Sodium and chloride accumulation in leaf, woody, and root tissue of Populus after irrigation with landfill leachate. Environ Pollut 155:72-80

Zekri M, Parson LR (1990) Response of split-root sour orange seedling to $\mathrm{NaCl}$ and polyethylene glycol stresses. J Exp Bot 41:35-40 